\title{
Det indirekte objekt i Fammers Minde: Et nedslag i en diakron proces
}

\author{
Peter Juul Nielsen
}

\begin{abstract}
Since the Middle Ages, the Danish indirect object (IO) has undergone a narrowing of its potential in terms of semantic role and its ability to occur without a valence slot provided by a 3-place verb, i.e. the possibility of free IOs. As a contribution to the understanding of the stages in this diachronic change, the article presents a study of the IOs found in the late 17th c. autobiography Fammers Minde by Leonora Christina. The study finds that the vast majority of IOs designate Recipients, and that free IOs are strikingly rare. The article examines the role of prepositional particles as valencyincreasers, IOs as external possessors, and verbs of communication in the IO construction.
\end{abstract}

\section{Nøgleord}

indirekte objekt, dansk sproghistorie, semantiske roller, valens

\section{Indledning}

De indirekte objekt $(\mathrm{IO})$ i moderne dansk har egenskaber der er resultatet af en lang historisk udvikling hvor rammerne for den ditransitive konstruktion med to objekter, direkte objekt (DO) og IO, og det semantiske potentiale for IO har undergået ændringer i form af en specialisering. Denne artikel er et nedslag i den diakrone proces frem til tilstanden i dag, nemlig en undersøgelse af IO i 1600-tallets dansk repræsenteret ved Leonora Christinas fammers Minde.

I moderne dansk optræder IO først og fremmest, ja næsten udelukkende, ved ditransitive verber - trivalente verber der specificerer en valensplads til tre nominale argumenter, subjekt (argument 1), DO (argument 2) og IO (argument 3). IO betegner prototypisk den semantiske rolle Modtager i en 
overdragelsesrelation med subjektet i kausativ rolle (jf. Hansen \& Heltoft 2011 (herefter GDS): 1305-1306, 1310). Det prototypiske IO-verbum er give (1). ${ }^{1}$

(1) Ib gav Bo en bog

Disse moderne træk ved IO som argument 3 står i kontrast til forholdene i ældre dansk som skitseres i følgende gennemgang af IO's udvikling.

\subsection{De store linjer fra middeldansk til nutidsdansk}

Som i andre germanske sprog (Barðdal 2007, Colleman 2011) er der sket en indsnævring og specialisering af IO's semantiske potentiale. I middeldansk var IO's kodede indhold en bred Interessentrolle, og det var ikke nødvendigt for IO-konstruktionen at betegne en overdragelse med IO som Modtager. På dette stadie var der vide muligheder for fri tilføjelse af IO, dvs. monotransitive konstruktioner med bare ét objekt kunne udbygges med et IO med rollen Interessent som i (4), hvor IO henne ikke betegner en modtager af hjulet, men en referent med en anden form for interesse eller involvering, her den involvering at skulle tortureres på hjulet (Heltoft 2019: 161, eksempel herfra).

(4) Vrbanus (...) lot henne eth hiull giøræ

Urbanus lod gøre et hjul til hende (fra Kristina-legenden)

Ifølge Høysgaard (1752: 108) var det stadig i 1700-tallets dansk muligt frit at tilføje IO med Interessentrolle uden overdragelsessemantik, fx at åbne nogen en dor og han skal lose os knuden (jf. Heltoft 2014). I 1800-tallet kan der konstateres en indsnævring omkring overdragelsessemantikken (ibid.). Frit IO med indholdet Intenderet Modtager (som konkret kan tolkes som faktisk modtager) ved anskaffelses- og fremstillingsverber er stadig muligt (5) - (6) (eksempler fra Heltoft 2014), men de rene interessenter er faldet bort (7).

(5) Naar Moderen havde købt ham en ny Kasket (roman 1911, forf. født 1860)

(6) Jeg byggede hende en Lykke-Verden (1869)

(7) *jeg åbnede hende døren

1 I alle eksempler er IO fremhævet med fed. 
I nutidsdansk ses en stadigt tydeligere indsnævring omkring overdragelsessemantik, og der er stærke begrænsninger på frit IO ved anskaffelses- og fremstillingsverber som nu kræver regulativ sproghandlingskontekst (8) - (10) (Nielsen \& Heltoft, under udg.)

(8) kunne du ikke lige købe mig en øl?

(9) skal jeg lave dig en kop kaffe?

(10) */?han købte naboen en $b^{2} g^{2}$

\subsection{Hvad skete der undervejs?}

For nærmere at undersøge den ovenfor beskrevne proces må man kortlægge IO's forekomster og potentiale på forskellige historiske trin undervejs, og det her fremlagte nedslag i 1600-tallet er et bidrag til denne kortlægning. Studiet af IO i fammers Minde undersøger IO's semantik gennem en beskrivelse af hvilke verber der optræder med IO, og hvilke forskellige semantiske roller IO har. I lyset af den ovenfor beskrevne historiske udvikling fokuserer artiklen særligt på mulighederne for IO med et andet indhold end det i dag dominerende, rollen Modtager, og mulighederne for tilføjelse af frit, ikkevalensbundet IO og de nærmere betingelser for tilstedeværelse af frie IO’er.

\subsection{Kilde og metode}

Kildemateriale er Leonora Cristinas Jammers Minde i Det Danske Sprogog Litteraturselskabs diplomatariske udgave fra 1998 (i eksempler fra teksten opgives sidetal og linjenummer fra denne udgave). Hele del I (ca. 1674) og del II (ca. 1692), 208 sider i udgaven (inkl. fortalen), er manuelt excerperet, og alle registrerede IO-forekomster er analyseret. ${ }^{3}$ Verberne i IO-konstruktion er klassificeret efter deres semantik. På baggrund af den ganske omfattende litteratur om IO-semantik (bl.a. Barðdal 2007, Barðdal, Kristoffersen \& Sveen 2011, Colleman 2011, Colleman \& De Clerck 2011, Zehentner 2017, Ibsen \& Refstrup 2002, GDS: 1304-1334) er der opstillet et kategoriseringssystem for IO-verbernes mulige semantik vist i tabel 1 . Eksempelverberne illustrerer de semantiske kategorier uden nødvendigvis

2 Det er ikke umuligt at finde nutidige eksempler på fx købe med IO i ikke-regulative kontekster, men det synes ikke at rokke ved de konklusioner der på empirisk grundlag drages i Nielsen \& Heltoft (under udg.).

3 Som IO'er er kun medtaget IO som positivled, dvs. som nominalt led, mens det præpositionelle modstykke, IO's antiled (GDS: 1183-1185), ikke er inkluderet. Refleksiver er udeladt da de ikke skal regnes for (egentlige) udtryk for argument 3 (jf. GDS: 592-594, Nielsen \& Heltoft, under udg.). 
at kunne optræde med IO i (moderne) dansk og uden nødvendigvis at optræde i fammers Minde. ${ }^{4}$

\begin{tabular}{|c|c|c|}
\hline Kategorier & Forklaring & Eksempelverber \\
\hline \multicolumn{3}{|l|}{ Overdragelse } \\
\hline Gennemført overdragelse & $\begin{array}{l}\text { Gennemførelse af DO til IO i og med } \\
\text { handlingen }\end{array}$ & give, bevilge \\
\hline Planlagt overdragelse & $\begin{array}{l}\text { Forberedelse af senere overdragelse af DO til } \\
\text { IO }\end{array}$ & $\begin{array}{l}\text { reservere, } \\
\text { efterlade }\end{array}$ \\
\hline Fratagelse & Omvendt overdragelse, IO mister DO & fratage, koste \\
\hline Kompensation & Overdragelse til IO af godtgørelse for DO & godtgøre \\
\hline \multicolumn{3}{|l|}{ Kommunikation } \\
\hline Meddelelsestype & Overdragelse af budskab (=DO) af en vis type & fortcelle, spørge \\
\hline Kommunikationsform & $\begin{array}{l}\text { Specifikation af måden eller redskabet til } \\
\text { overdragelse af budskab (=DO) }\end{array}$ & råbe, skrive \\
\hline \multicolumn{3}{|l|}{ Regulativ } \\
\hline Handlingskommissiv & $\mathrm{S}$ forpligter sig til at udføre handling (=DO) & tilbyde, love \\
\hline Overdragelseskommissiv & S forpligter sig til at overdrage DO & tilbyde, love $e^{5}$ \\
\hline Udførelsesdirektiv & S søger at få IO til at udføre handling (=DO) & tillade, pålagge \\
\hline Undladelsesdirektiv & S søger at få IO til at afstå fra handling (=DO) & fraråde, forbyde \\
\hline $\begin{array}{l}\text { Muliggørelse og } \\
\text { facilitering }\end{array}$ & $\begin{array}{l}\text { S gør det muligt eller lettere for } \mathrm{IO} \text { at besidde } \\
\text { eller håndtere DO }\end{array}$ & lette, forunde \\
\hline \multicolumn{3}{|c|}{ Forårsagelse af intern proces } \\
\hline $\begin{array}{l}\text { Forårsagelse af } \\
\text { perception }\end{array}$ & $\mathrm{S}$ forårsager en perceptionsoplevelse i IO & vise \\
\hline Forårsagelse af kognition & $\mathrm{S}$ forårsager en kognitionsproces i IO & laere, forklare \\
\hline \multicolumn{3}{|l|}{ Hindring } \\
\hline Hindring af overdragelse & $\begin{array}{l}\text { S hindrer eller vanskeliggør overdragelsen af } \\
\text { DO til IO }\end{array}$ & forholde, noegte \\
\hline Hindring af handling & $\begin{array}{l}\text { S hindrer eller vanskeliggør IO's udførelse af } \\
\text { handling (=DO) }\end{array}$ & forhindre \\
\hline Fremstilling og klargøring & $\begin{array}{l}\text { DO skabes eller gøres klar til et/dets formål af } \\
\text { S }\end{array}$ & bage, bygge \\
\hline Anskaffelse & DO tilvejebringes af $\mathrm{S}$ & købe, finde, skaffe \\
\hline Flytning & $\begin{array}{l}\text { DO flyttes fra ét sted til et andet (evt. til } \\
\text { deiktisk centrum) }\end{array}$ & sende, bare, kaste \\
\hline Manipulation af genstand & Ikke-tilvejebringende handling rettet mod DO & åbne, vaske \\
\hline Påvirkning & $\begin{array}{l}\text { S udsætter IO for handling el. omstændighed } \\
\text { (=DO) }\end{array}$ & $\begin{array}{l}\text { gøre (nogen } \\
\text { noget), forårsage }\end{array}$ \\
\hline Attituder og følelser & S's indstilling til relationen mellem IO og DO & misunde, tilgive \\
\hline
\end{tabular}

Tabel 1: Kategorisering af IO-konstruktionernes verbers semantik

4 I forklaringen af kategoriernes semantik er subjektsreferent, DO-referent og IO-referent forkortet til S, DO og IO.

5 Ved handlingskommissiv vil DO for fx tilbyde og love være neksualt, ved overdragelseskommissiv inneksualt. 


\section{IO iJammers Minde}

Efter frasortering af 17 tilfælde af visse faste forbindelser der vurderes irrelevante for IO-analysen, primært hilseudtryk såsom give hånd og gøre la reverence, fremkommer et datasæt på 467 IO-forekomster i fammers Minde del I og II. IO-konstruktionernes verballeksemer er ordnet sådan at et verbum med flere betydningsfunktioner - fx befale med betydningerne 'byde, påbyde' og 'overgive, betro' - regnes for ét verbum, men henregnes til forskellige semantiske kategorier alt efter betydningsvariant i eksemplet. Det betyder at nogle verber optræder i flere semantiske kategorier i tabel 3 med resultaterne. Visse sammensætninger af verbum + andet materiale regnes for særskilte leksemer; det gælder fx mere eller mindre faste forbindelser af verbum og adverbielt materiale, fx bringe til veje og give til kende. Derfor finder man i tabel 3 fx både give ('overdrage') og give til kende ('meddele'). Verber der i IO-konstruktion altid optræder sammen med en præpositionspartikel (se afsnit 3.3), angives med den "faste" præposition. Ved verber som optræder i IO-konstruktion både med og uden en sådan præposition, fx skrive med og uden det til der vises i (11), er alle forekomster regnet til samme verballeksem (som figurerer uden præpositionen).

(11) Ieg wiste wel att Christian skulle byde paa, att skriffwe mig til alle haande nyt (157.7-9)

Opdelt efter disse principper findes der i de 467 IO-eksempler 86 forskellige verber (eller præcisere: prædikater i form af simple verbalstammer og semantisk tæt forbundne sammensætninger). Alle verberne kan ses i tabel 3, hvor de er inddelt efter semantiske kategorier. Et lille sæt af verber står for langt størstedelen af IO-forekomsterne. I tabel 2 ses de 11 hyppigste verber ${ }^{6}$ som tilsammen findes i 303 forekomster der udgør $64,88 \%$ af alle IO-fund.

6 Fremfor det pæne runde 10 er 11 oplistet fordi nr. 10 og 11 begge har 8 forekomster, nr. 12 (berette) kun 7. 


\begin{tabular}{|l|r|r|}
\hline Verbum & Antal & \% af samlet $\mathbf{( 4 6 7 )}$ \\
\hline sige & 68 & $14,56 \%$ \\
\hline give & 65 & $13,92 \%$ \\
\hline fly & 44 & $9,42 \%$ \\
\hline spørge & 42 & $8,99 \%$ \\
\hline gøre noget/tjeneste/ulykke m.fl. & 18 & $3,85 \%$ \\
\hline befale & 16 & $3,43 \%$ \\
\hline sende & 16 & $3,43 \%$ \\
\hline bede & 9 & $1,93 \%$ \\
\hline skrive & 9 & $1,93 \%$ \\
\hline love & 8 & $1,71 \%$ \\
\hline locre & 8 & $1,71 \%$ \\
\hline De 11 hyppigste verber i alt & 303 & $64,88 \%$ \\
\hline
\end{tabular}

Tabel 2: De 11 hyppigste verber i IO-konstruktion med individuel og samlet andel

De fire hyppigste verber alene - som har markant flere forekomster end de efterfølgende på listen - står for 219 forekomster og udgør 46,90 \%. 52 af de 86 verber optræder kun en eller to gange.

I tabel 3 vises IO-forekomsterne fordelt efter verbernes semantiske kategorier. Bemærk at tabellen kategoriserer efter verbernes semantik, ikke efter den betydning der udtrykkes i kraft af IO-konstruktionen. ${ }^{7}$ For de kategorier der har underkategorier, vises antal og procentdel dels for overkategorien, dels for underkategorierne.

7 Ved verber der styrer IO, vil verbets semantik give en dækkende beskrivelse af semantikken i den pågældende instantiering af IO-konstruktionen, herunder en bestemmelse af IO's indhold (fx som Modtager). Ved verber der ikke styrer IO, indeholder beskrivelsen af verbets semantik ikke en bestemmelse af IO-konstruktionens eller IO-leddets indhold; i så fald er IO-semantikken rent konstruktionel. 


\begin{tabular}{|c|c|c|c|}
\hline $\begin{array}{l}\text { Semantisk kategori } \\
\text { (verbets semantik) }\end{array}$ & Verber & Antal & $\begin{array}{l}\% \text { af } \\
\text { samlet } \\
(467)\end{array}$ \\
\hline \multicolumn{2}{|l|}{ Overdragelse } & 132 & $28,27 \%$ \\
\hline Gennemført overdragelse & $\begin{array}{l}\text { befale }^{8} \text { betro, bevilge, fly, forcere, give, } \\
\text { indskyde, lade, levere, lagge (på), låne, } \\
\text { meddele, overlevere, påloegge, rakke, } \\
\text { tillagge, tilregne, tilstede, tilstille }\end{array}$ & 120 & $25,70 \%$ \\
\hline Planlagt overdragelse & ordinere & 1 & $0,21 \%$ \\
\hline Fratagelse & betage, fratage & 8 & $1,71 \%$ \\
\hline Kompensation & belønne, betale & 3 & $0,64 \%$ \\
\hline \multicolumn{2}{|l|}{ Kommunikation } & 164 & $35,12 \%$ \\
\hline Meddelelsestype & $\begin{array}{l}\text { adspørge, advare, andrage, berette, } \\
\text { foreholde, formcelde, forsikre, forstcendige, } \\
\text { fortro, fortcelle, give til kende, gøre } \\
\text { spørgsmål/løfter, holde (for), klage, lyve (på), } \\
\text { sige, spørge, svare, svarge (til), tilskrive, }{ }^{10} \\
\text { tilspørge, true }\end{array}$ & 154 & $32,98 \%$ \\
\hline Kommunikationsform & råbe (til), skrive & 10 & $2,14 \%$ \\
\hline \multicolumn{2}{|l|}{ Regulativ } & 53 & $11,35 \%$ \\
\hline Handlingskommissiv & forsikre, love, svaerge (til) & 9 & $1,93 \%$ \\
\hline Overdragelseskommissiv & byde, love, tilbyde & 10 & $2,14 \%$ \\
\hline Udførelsesdirektiv & bede, befale, overtale, persuadere, tilstede & 28 & $6,00 \%$ \\
\hline Undladelsesdirektiv & forbyde & 6 & $1,28 \%$ \\
\hline Muliggørelse og facilitering & forunde, unde & 5 & $1,07 \%$ \\
\hline \multicolumn{2}{|c|}{ Forårsagelse af intern proces } & 12 & $2,57 \%$ \\
\hline Forårsagelse af perception & vise, åbenbare & 3 & $0,64 \%$ \\
\hline Forårsagelse af kognition & gøre bekendt, laere & 9 & $1,93 \%$ \\
\hline \multicolumn{2}{|l|}{ Hindring } & 6 & $1,28 \%$ \\
\hline Hindring af overdragelse & forholde, noegte & 3 & $0,64 \%$ \\
\hline Hindring af handling & forhindre & 3 & $0,64 \%$ \\
\hline Fremstilling og klargøring & gøre, hegle 11 & 5 & $1,07 \%$ \\
\hline Anskaffelse & $\begin{array}{l}\text { bringe til veje, fly, forskaffe, prokurere, } \\
\text { skaffe, tage }\end{array}$ & 27 & $5,78 \%$ \\
\hline Flytning & bare, hange, sende, skaffe, satte & 27 & $5,78 \%$ \\
\hline Manipulation af genstand & drage (af), støde (af) & 2 & $0,43 \%$ \\
\hline Påvirkning & $\begin{array}{l}\text { bevise, }{ }^{12} \text { forelagge, }{ }^{13} \text { gøre noget/tjenestel } \\
\text { ulykke m.fl., tilskikke }\end{array}$ & 24 & $5,14 \%$ \\
\hline Attituder og følelser & $\begin{array}{l}\text { beklage, beskylde, byde, forlade, tilgive, } \\
\text { ønske }\end{array}$ & 10 & $2,14 \%$ \\
\hline \multicolumn{2}{|l|}{ I alt } & 467 & $100 \%$ \\
\hline
\end{tabular}

Tabel 3: Fordeling af verber i IO-konstruktion efter verbernes semantiske kategorier med antallet af IO-forekomster

8 Her i betydningen 'overgive, betro'.

9 'Give (nogen) del i noget som man har, tilstå, overlade', ikke i kommunikationsbetydningen 'gøre (nogen) bekendt med'.

10 'Skrive noget til nogen', ikke 'tillægge (fx egenskab)'.

11 'underkaste en slags kæmning med en hegle'.

12 'Gøre (noget, typisk noget godt) imod (en)'.

13 'Bestemme (noget) som gældende (for en), byde som vilkår'. 
Som man ser i tabel 3, udgør overdragelse, kommunikation og regulativer langt størstedelen af verberne og af IO-forekomsterne - tilsammen 349 forekomster der udgør $74,73 \%$ af de 467 . Det viser sig at der er uhyre få forekomster af verber der ikke styrer deres IO, hvor altså IO er en fri tilføjelse (se afsnit 3).

\subsection{IO's semantiske rolle}

Som det fremgår af tabel 3, er langt de fleste af de fundne IO-konstruktioner i kraft af verbets leksikalske semantik udtryk for en overdragelse i mere eller mindre direkte og konkret forstand hvor IO dermed har rollen Modtager. Det gælder for de 28,27 \% hvor verbet betegner egentlig overdragelse (gennemført, planlagt eller omvendt (fratagelse) og den komplekse kompensationsoverdragelse), $\mathrm{fx}(12), \mathrm{og}$ for de 35,12\% hvor verbet betegner kommunikationshandlinger, $\mathrm{fx}$ (13), som kan ses som en metaforisk overdragelse fra subjektsreferent til IO-referent hvor meddelelsens indhold - "teksten", betegnet af DO - formidles til IO-referenten (GDS: 1310).

(12) Ieg swarte att wille lewere hender et Regiment lopper om hun wille haffwe dem? (178.24-179.2)

(13) Pær berettede omsier quinden att ded war twende Fransoser (91.4-5)

Tilsammen udgør disse to grupper 63,39 \% af alle IO-forekomsterne. Dertil kommer overdragelseskommissiverne $(2,14 \%)$ hvor subjektsreferenten forpligter sig til at overdrage DO-referenten til IO-referenten, og verber der betegner hindring af overdragelse $(0,64 \%)$.

I en række verbaltyper er det karakteristiske ikke åbenlyst det at IO betegner en modtager af en overdraget genstand, men at IO er et argument $i$ en af DO betegnet prædikation (dvs. DO betegner et sagforhold som har IO-referenten som aktant). Som argument i DO-prædikationen kan IO da enten være Agent (indholdssubjekt), eller det kan en Interessent (eller ligefrem Patient) ift. DO-prædikationer hvor IO-konstruktionens subjekt er Agent. Det gælder ved kategorierne hindring af handling (14), handlingskommissiver (15), direktiver (16) og udtryk for påvirkning (17) og attituder og følelser (18) (med angivelse af IO's rolle i DO-prædikationen).

... Saa den Raaben forhindrede mig [Agent] att soffwe (157, margin) 
(15) [hun] Bød mig goede Natt, oc loffuede mig [Interessent] flittig i sine Bønner att Ihuekomme (62.6-7)

(16) G. Rantzow befalede den som med Papired indkom [Agent] att oplæsse (50.9-10)

(17) Ieg fryctede intet for ded onde hand kunde giøre mig [Interessent/ Patient] $(151.10-11)^{14}$

(18) hiertelig gierne forlader ieg eder [Agent] ded (118.8)

I den slags IO-konstruktioner, og ved den slags verber, hvor IO gøres til argument i DO, er det ikke oplagt at opfatte IO som en modtager af DO. Udover argumentrollen kan IO dog ofte opfattes som en Interessent ift. verbalhandlingen, fx i (18) hvor det kommer IO-referenten til gode at subjektsreferenten giver tilgivelse.

Trods konstruktioner af type i (14) - (18), kan det dog overordnet siges at i alle de tilfælde hvor verbet styrer IO som argument 3 , står dette argument 3 i en relation til argument 2, DO, prototypisk som Modtager i konkret eller abstrakt forstand. Der hvor modtagerforholdet ikke er så tydeligt, udtrykker verbet ofte at IO er Agent (indholdssubjekt) i en prædikation udtrykt af DO, og på den måde kan man sige at IO og DO "bringes sammen". Det særligt interessante er IO's semantiske rolle ved verber der ikke styrer IO, hvor IO altså er en fri tilføjelse, en konstruktionsmulighed der ikke er skabt af verbets valens. Dette tages op nedenfor.

\section{Frit IO}

Som nævnt i afsnit 1.2 har de frie IO'er særlig interesse, og resultatet af undersøgelsen af frie IO’er i Jammers Minde fremlægges i dette afsnit.

I en undersøgelse af mulighederne for fri tilføjelse af et IO der ikke er valensled til verbet, er det naturligvis afgørende at bestemme om et givent verbum der optræder med IO, er ditransitivt og styrer sit IO, eller det er monotransitivt og kun styrer sit DO, mens IO er en fri konstruktionel udbygning. Der kan opstilles et semantisk-begrebsligt kriterium for valensstyret og frit IO. GDS beskriver det sådan at et valensstyret IO er et semantisk nødvendigt argument i den forstand at det indgår obligatorisk i den situation, det sagforhold, som verbet betegner, også - rent tolkningsmæssigt - hvis det er udeladt i udtrykket (GDS: 1308, jf. Nielsen \& Heltoft, under udg.).

14 ded onde har ikke direkte prædikationsform, men kan betragtes som et neksualt nominal der betegner (et) sagforhold (onde gerninger). 
Modsat er det semantisk karakteristiske for det frie IO at det ikke indgår i verbalstammens begrebslige struktur; er det frie IO ikke til stede, så er der i indholdsstrukturen ikke noget IO-argument (GDS: 1328, Heltoft 2014: 205).

Også syntaktisk opførsel kan inddrages i bestemmelsen af valensforholdene: De valensstyrede IO'er kan opskrives til subjekt i passiv (19), mens dette ikke er en mulighed for frie IO'er (GDS: 1308, 1311). På baggrund heraf viser Heltoft (2014: 229-231) at moderne dansk skaffe, som ud fra sin betydning og sin forekomst både med og uden IO kunne ligne et ditransitivt verbum, ikke styrer IO idet IO ved skaffe ikke kan opskrives til subjekt (20) (jf. GDS: 1311).

\section{hun blev tilbudt en billet}

*hun blev skaffet en billet

Det særlige ved skaffe er at verbets tilvejebringelsessemantik koder den præsupposition at nogen ønsker at have DO-referenten til rådighed (Heltoft 2014: 230), og dette gør det muligt at konstruere skaffe med frit IO trods de skrappe restriktioner på frit IO i moderne dansk (jf. afsnit 1.1).

\subsection{Tilfaeldet $\mathbf{f y}$}

Hvad angår spørgsmålet om Jammers Minde-verbernes IO-styring, udgør fly et særligt problem. Det er med sine 44 forekomster det 4 . hyppigste IO-verbum, men verbets polysemi gør det vanskeligt at bestemme IO som valensled eller ej. På basis af ODS og Kalkars ordbog kan man opstille tre hovedbetydninger:

1. ordne, indrette, istandsætte

2. tilvejebringe, skaffe

3. give, række

I betydning 1 er intet IO-argument impliceret. ${ }^{15}$ I 2 tilvejebringes noget så det er til rådighed for nogen, men denne nogen kan være subjektet selv, dvs. den tilvejebringende, eller det kan være en tredje størrelse udtryk med IO. I 3 profileres overdragelsen til en IO-referent af en genstand der er i

15 Det er tilmed ikke engang nødvendigt at der indgår en genstand der (potentielt) kunne overdrages, jf. dette eksempel fra Kalkar hvor fly betyder 'ordne eller arrangere omstændigheder': ieg skal fly det saa, at hedningene skulle vederkendiss dig (fra Chr. Pedersens oversættelse af Det Nye Testamente, 1531). 
subjektreferentens besiddelse. 1 lægger stærkt op til en tolkning af IO som frit, mens 3 meget tydeligt etablerer et IO-argument som her forekommer valensstyret. 2 minder meget om betydningen af moderne dansk skaffe, og man kunne derfor overveje samme tolkning som Heltofts skaffe-analyse: IO er frit, men muliggjort af en semantisk præsupposition af nogens ønske om tilvejebringelse og besiddelse.

Et forsøg på at afklare statussen for IO ved fly ud fra passivforholdene har foreløbigt ikke ledt til nogen nærmere afklaring. Passivmulighederne for fly på Leonora Christinas tid kan selvsagt ikke undersøges gennem introspektion, men må baserede udelukkende på brugen af fly i fammers Minde og andre kilder fra perioden. Ingen af $f l y$-sætningerne i fammers Minde er passive (hverken med opskrivning af DO eller IO eller uden opskrivning), og en gennemgang af forekomster af $f y$ i teksterne på renaessancedansk.dk gav heller ikke nogen passiver, hverken i monotransitiv eller ditransitiv konstruktion. Dette fravær af IO'er opskrevet til subjekt i passiv beviser ikke at $f y$ ikke styrer IO, idet fraværet ikke beviser umuligheden, og eftersom passive IO-konstruktioner i det hele taget forekommer meget sparsomt i de ældre kilder, kan fraværet af $f y$-IO-passiver ikke engang anses for så påfaldende at det må regnes for indicium på umuligheden af opskrivning.

I Jammers Minde bruges fly kun i betydning 2 (19 forekomster med IO) som i (21) og 3 (25 forekomster med IO) som i (22), aldrig i betydning 1 .

(21) Ieg sagde giffuer Pær goede Ord, saa flyer hand eder wel noget Hør for penge, oc en Haand-teen (100.21-23)

(22) Ieg tog dennem aff oc flyde hender (19.2-3)

Ud over de 44 forekomster i IO-konstruktion findes der 4 forekomster af fly uden IO som alle har betydning 2: 'skaffe' eller 'tilvejebringe', og i mindst ét tilfælde er det klart fra konteksten at en tredjepart har ønske om tilvejebringelsen. De her beskrevne forhold omkring fly i fammers Minde gør det vanskeligt at afgøre om et IO ved $f y$ skal betragtes som frit eller styret, eller evt. styret når $f y$ har betydning 3 ('give, række'), men frit ved betydning 2 ('tilvejebringe, skaffe'). At fy i Jammers Minde aldrig har den mest "fri-IO-motiverende" betydning (betydning 1: 'ordne, indrette, istandsætte') kunne lægge op til den konklusion at ingen IO'er ved fly i fammers Minde bør betragtes som frie, men en sådan afgørelse må bero på en mere principiel teoretisk overvejelse om forholdet mellem polysemi og valens som ligger uden for denne artikel. På baggrund af de beskrevne vanskeligheder med fy klassificeres IO’er ved $f y$ i nærværende undersøgelse ikke som tilfælde 
af frit IO bortset fra to ganske særlige tilfælde som skal beskrives nærmere nedenfor. Den generelle frasortering af IO ved fly fra kategorien frit IO kan betragtes som et metodologisk begrundet valg: Undersøgelsen har bl.a. som mål at identificere frie IO'er som antages at være mere almindelige i ældre tekster, og er der ikke tilstrækkeligt sikkert grundlag for at beskrive en IO-forekomst som et frit IO, sorteres den fra. ${ }^{16}$

\subsection{Frie IO'er $i$ Jammers Minde: verber og semantiske roller} Antallet af frie IO'er i Jammers Minde er meget lavt, især hvis man fraregner den særlig gruppe af konstruktioner hvor verbet gore + neksualt DO tilsammen udtrykker noget der påvirker IO-referenten. Der er i alt, inkl. påvirkningskonstruktioner, 41 IO'er der kan analyseres som frie; de udgør $4,73 \%$ af det samlede antal. De falder i tre hovedgrupper hvad angår semantisk rolle.

\subsubsection{Patient-lignende Interessent $i$ påvirkningskonstruktioner med gøre}

18 IO-konstruktioner er af den semantiske type 'påvirkning' hvor verbet gøre kombineres med et neksualt DO som betegner en handling som IOreferenten udsættes for, ikke som Modtager ved overdragelse af DO, men som en art Patient der bydes DO-handlingen som vilkår (23) - (24).

(23) Giør ieg eder noget? (118.22)

(24) Hun giorde mig allehaande fortred, som ieg tog imod med taalmodighed (185.6-7)

IO er i disse konstruktioner frit i den forstand at verbalhandlingen i fx gøre noget ikke forudsætter et IO-argument der udsættes for dette 'noget'. Man kan dog også opfatte gøre noget og gøre fortred m.fl. som faste forbindelser af gore som et 'let verbum' (Butt 2010) og det neksuale led som en del af prædikatet hvorved det element der fremstår som et IO, ikke bør regnes for ægte IO, men i virkeligheden en slags DO.

16 I min analyse er IO ved skaffe og sende, der i GDS' analyse af moderne dansk betegnes som frit IO (GDS: 1311), ikke regnet for frit, primært fordi jeg ikke er parat til at forpligte mig på denne analyse, men også fordi skaffe og sendes forekomst med IO i Jammers Minde ikke i sig selv forekommer bemærkelsesværdigt. 


\subsubsection{Modtager af DO-referent, herunder potentiel modtager}

Der er 14 eksempler på frie IO'er med Modtagersemantik (hvor det ikkeIO-styrende verbum vel at mærke ikke har leksikalsk kodning af betydningen 'overdragelse til modtager'). De forekommer ved anskaffelsesverberne bringe til veje og tage (25), flytningsverbet bere (26) og fremstillingsverberne gøre (27) og hegle ('underkaste en slags kæmning med en hegle') (28).

(25) Om Afftenen sneeg hand sig til, oc sagde til hender i ded vderste Rom; tar mig hid Sax oc Kniif (158.23-24)

(26) oc bar Balcke mig nogle Linklæder, som hun aff miine endnu haffde til offwers (123.21-23)

(27) giør mig deraff en Rem i miine Boxer [dvs. bukser] (113.4-5)

(28) oc sagde ieg til hender, der haffwer i noget att giøre hægler mig $\operatorname{ded}(138.10-11)^{17}$

\subsubsection{Ren Interessent uden reel eller potentiel overdragelse}

I 7 tilfælde udtrykker IO en interessent der ikke (også) er faktisk eller potentiel Modtager. I to tilfælde med $f y$ i overdragelsesbetydning er målet for overdragelsen adverbielt angivet (med til), mens IO betegner den der nyder godt af overdragelsen uden selv at modtage noget (29). Noget lignende gælder i et enkelt tilfælde med skaffe i betydningen 'flytte noget fra eller til et sted'.

(29) Den Schelm wiste wel att ieg haffde intet laded mig mercke for quinden hwercken om ded hand haffde flyet mig bud til Skaane til miine børn ... (157.19-22)

Man finder også manipulationsverbet drage (af) (30) og flytningsverbet sette (31).

(30) Hun drog mig alle mine Klæder aff (19.13-14)

(31) Marens hænder rystede, der hun satte mig Tøfflerne paa (65.1314)

17 Formene tar i (25) og hagler i (28) er imperativ pluralis, her brugt som høflighedsform over for modtageren (som er én person). 


\subsubsection{Tilfeldene støde $o g$ hænge}

I tillæg til disse tre grupper kommer to eksempler med verberne støde (32) og hange (33) hvor IO dårligt kan beskrives som Modtager eller Interessent, men synes at være ren ekstern possessor (se nærmere i afsnit 4.2).

(32) hun falt imod sin Slabenk oc støtte sit Skinnebeen hudden aff (186.13-14)

(33) [ieg] skreff noget paa en Seddel oc hengte hender om halsen (166, margin)

\subsubsection{Opsamling på frit $I O$}

Fraregner man de måske tvivlsomme IO'er i påvirkningskonstruktionerne med gore, står vi tilbage med 23 tilfælde af frit IO, blot 2,65 \% af alle IO'erne. Det er værd at bemærke at kun to fremstillingsverber, gore og hegle, optræder med frit IO, og det i kun 5 tilfælde. Det er også værd at bemærke at det reneste monotransitive anskaffelsesverbum, tage, ${ }^{18}$ kun forekommer én gang i IO-konstruktion. Endelig skal det bemærkes at konstruktionen med tage og det eneste tilfælde med hegle samt to af de fire tilfælde med gøre udtrykker regulative sproghandlinger (jf. (25), (27) og (28)). Datagrundlaget er for spinkelt til robuste konklusioner, men det er påfaldende at de dermed flugter med kravet om regulativ sproghandlingsramme for frie IO'er i moderne dansk (jf. afsnit 1.1).

\section{Andre bemærkelsesværdige IO-konstruktioner}

Udover konstruktion med frit IO er der en række andre typer af IOkonstruktion der er værd at bemærke som udtryk for sprogtilstanden i fammers Minde, og som gennemgås i dette afsnit: forekomster af IO med en partikellignende præposition (afsnit 4.1), fænomenet ekstern possessor (afsnit 4.2) og kommunikationsverber med IO (afsnit 4.3).

\subsection{Opskrivning fra prapositionsled}

Ganske ofte optræder IO med en "strandet præposition" der står som en form for partikel enten efter IO og DO eller mellem de to objekter. Det ses i (34) med lagge + på og i eksemplerne ovenfor med drage + af (30), satte + på (31) og stode + af (32).

18 Man kan argumentere for at bringe til veje har indbygget en forestilling om en potentiel modtager i højere grad end tage. 
(34) Min Trøst oc Bistand werret haffuer, thi aldrig lagde Gud mig saa snart en Byrde paa, att hand io med ded samme mig effter Byrdens tyngde Styrcke gaff, saa att Byrden mig wel Krum nederbøyede $\left(3^{*} .1-4\right)$

Strukturen findes også i andre kilder, fra samtiden som i (35) med legge + til og fra 1500-tallet som i (36) med røve + fra.

(35) Men efftersom hun var aff formue, torde ingen vel legge hende det til (Brunsmand 1674: 139)

(36) paa det hand iche skal $\underline{\text { røffue }}$ eder eders retfongen arbeed fraa (Palladius, c. 1543: 122)

Konstruktionstypen ligner en form for opskrivning af styrelsen i et præpositionsled til et primærled i sætningen, sammenlign (31) med hun satte toflerne på mig og (36) med han rovede noget fra dem.

Mange af eksemplerne er meget lig præfigerede verber, jf. påsatte og frarøve, og partikelpræpositionens funktion kunne se ud til at være valensforøgelse hvorved monotransitive verber ( $\mathrm{fx}$ satte) gøres ditransitive. Dermed vil kombinationen af et i udgangspunkt monotransitivt verbum og en præpositionspartikel kunne betragtes som en form for syntaktisk applikativkonstruktion (jf. Zúñiga \& Kittilä 2019: 12). ${ }^{19}$

Partikelkonstruktionen findes også i Jammers Minde ved en række kommunikationsverber, fx råbe + til, lyve + på (37), skrive + til og sverge + til (38).

(37) I kand lyffwe mig saa meget paa, som ieg wed intet aff(118.23-24) (38) att hand soer hender $\underline{\text { til}}$, att hun aldrig kom vd saa lenge hun leffte (96.1-2)

I kommunikationsudtrykkene synes præpositionen at præcisere retningen eller målet for den kommunikative overførsel, som en eksplicitering og specificering af det rumlige aspekt af den i kommunikationsverberne inhærente rettethed.

19 I Zúñiga \& Kittilä (2019) beskrives dog kun applikativer der dannes verbalmorfologisk eller med hjælpeverber; syntaktisk applikativkonstruktion af den her skitserede type synes ikke at være beskrevet i den gængse typologiske litteratur. 


\subsection{Ekstern possessor}

Det er kendt fra mange sprog at visse "dativer" (egentlige kasusbøjede dativer og andre dativlignende led, fx IO'er) kan stå i en possessionslignende del-helhed-relation til enten DO (39) eller (en nominal styrelse i) et præpositionsled (40) (Haspelmath 1999, eksempler herfra).

(39) Die Mutter wusch dem Kind die Haare ART.NOM moder vasker ART.DAT barn ART.AKK hår 'moderen vasker barnets hår'

(40) Fred gooit Sylvia een krant naar het hoofd Fred kaster Sylvia ART avis på ART hoved 'Fred kaster en avis i hovedet på Sylvia'

Konstruktionstypen kaldes possessordativ eller ekstern possessor, sidstnævnte betegnelse fremhæver at possessoren til DO eller præpositionstyrelsen (som possessum) ikke står internt i NP'en, fx som en genitivattribut (jf. barnets hår i oversættelsen af (39)), men som et selvstændigt sætningsled der er eksternt ift. possessum.

Som nævnt i behandlingen af eksemplerne i afsnit 3.2.4 må nogle IOkonstruktioner i fammers Minde tolkes som konstruktion med ekstern possessor. Det gælder for fire eksempler, alle med frit IO og med verber der betegner flytning eller manipulation af genstand. I eksemplet med støde $\mathrm{i}$ (32) er der del-helhed-relation mellem IO sit Skinnebeen og DO hudden, og i eksemplet med hange i (33) mellem IO hender og præpositionsstyrelsen halsen. I to forekomster med satte består relationen mellem IO mig (41) og Kongen (42) og præpositionsstyrelsen Brystet.

(41) de satte mig Degen oc Pistoll paa Brystet (1 $1 * .4)$

(42) ded war saae, att dersom man haffde sat Kongen Pistolen paa Brystet, da skulle hand ded forlade (192, margin)

Konstruktionen med ekstern possessor ser ud til at være en syntaktisksemantisk strategi for at muliggøre et IO der ikke er bundet af verbet. Del-helhed-relationen understøtter tilstedeværelsen af IO-argumentet, og man kan her tale om et frit IO som dog ikke er ganske frit, men bundet i possessionsrelationen. 


\subsection{IO-konstruktion med kommunikationsverber}

Den største kategori af IO-konstruktioner i Fammers Minde er kommunikationsudtryk, og blandt de kommunikationsverber der optræder i IOkonstruktion (jf. tabel 3), finder man adskillige som ikke i moderne dansk kan konstrueres med IO: advare (43), klage (44) og true (45).

(43) Maren adwarede mig, att en aff de toe Quinder som skulle tage ware paa mig, war Kongens Skomagers Quinde en Tydsk, oc meget wel lied aff Dronningen (29.12-15)

(44) Der Slozf. dennem effter helssen spurt haffde huor dennem Liidde, om de endnu leffuede, oc de hannem derris Tilstand klaget haffde, bød hand dennem Brendewin, huor imod de toge med begge Hænder (32.4-7)

(45) hand truede quinden att skulle fordriffwe henders latter (151.9-10)

Det hyppigste kommunikationsverbum - og det hyppigste IO-verbum overhovedet (jf. tabel 2) - er sige, et verbum der i moderne dansk kun forekommer med IO i noget der minder om faste vendinger som kan du sige mig hvad klokken er?, men ikke produktivt med fx at-sætning som DO (*jeg sagde ham at klokken var fem). I Jammers Minde myldrer det med sige-IO’er (46) - (48).

(46) Hand sagde hinder himligen, att hun skulle komme til Dronningen (28.3-4)

(47) Om Morgenen imod Middag, sagde ieg hender hwad hun skulle sige Christian (153.14-16)

(48) Oc efftersom hun mig tilforne sin Herkomst sagt haffde, saa tog hun saa meget diss wære mit Spørssmaal op, oc bleff heel fortørnet $(58.18-20)$

I moderne dansk må sige, ligesom mange andre kommunikationsverber (fx råbe, hviske og skrive) konstrueres med det præpositionelle modstykke til IO, det middelbare IO (IO's antiled), formentlig fordi denne type verbum specificerer det mål som kommunikationen rettes mod, men ikke en gennemført overdragelse af meddelelsen til modtageren (Ibsen \& Refstrup 2002: 73-79; GDS: 1350-1351). Konstruktion med sige og middelbart IO findes der også en hel del eksempler på i Jammers Minde (49), men ud fra de mange forekomster med IO lader det ikke til at spørgsmålet om kommunikationsmål vs. gennemført kommunikativ overdragelse spiller den samme rolle i Leonora Christinas sprog som i moderne dansk. 

huad skal wii sige til Dronningen? (61.17-18)

Det samlede billede af IO med kommunikationsverber er en ift. moderne dansk langt større åbenhed for IO-konstruktion mht. verbernes semantik, fx at illokutionsverber som advare og true forekommer med IO.

\section{Konklusion: hvor er vi henne i processen?}

Det er nu tid til at samle op på resultaterne og se dem i lyset af IO-konstruktionens diakroni. Analysen har vist at langt de fleste IO'er man finder i fammers Minde, ligner moderne dansk IO, og dermed kan det der adskiller Leonora Christinas sprogtilstand fra nutiden, nemt drukne i lighederne; når man betragter det samlede sæt af fundne IO-forekomster, ser 1600-tallets IO generelt ikke ud til at adskille sig meget fra nutidens.

I den meget lille gruppe af IO-forekomster der faktisk viser noget der er anderledes, er det særligt de frie IO'er der påkalder sig opmærksomhed, idet brugen af frit IO placerer Leonora Christinas 1600-talsdansk på et vigtigt udviklingsspor fra middeldansk til i dag. Man kan konstatere at der er meget få forekomster af frit IO (med meget få forskellige verber), og hvad angår hyppighed må frit $\mathrm{IO}$ således betragtes som en perifer brug af IO-konstruktionen.

Det er bemærkelsesværdigt at frit IO ved tilvejebringelsesverber - i materialet verberne tage, gore og hegle - allerede i slutningen af 1600-tallet synes at tendere mod regulative kontekster. Som sagt er grundlaget for konklusioner desangående foreløbigt meget beskedent, men resultaterne af undersøgelsen af Jammers Minde antyder at processen der har ført til den moderne situation hvor regulativ kontekst kan betragtes som et krav (Nielsen \& Heltoft, under udg., jf. afsnit 1.1), går mange hundrede år tilbage.

Ud fra afdækningen af de forskellige typer af IO-konstruktion i fammers Minde kan man opstille en række forskellige former for binding af IO, det der er bestemmende for IO-muligheden. I den rent leksikalske ende finder vi valensbinding hvor $\mathrm{IO}$ er styret af et ditransitivt verbum. I konstruktionen med "strandet" præposition kan man tale om præpositionsbinding $\mathrm{i}$ den forstand at IO i den syntaktiske applikativkonstruktion der danner et ditransitivt prædikat, er styret af præpositionen (jf. ligheden mellem han rovede dem noget fra og han rovede noget fra dem, sidstnævnte med dem som styrelse til præpositionen $f r a$ ). Et skridt længere væk fra prædikatsdannelsen og længere ud i syntaksen er possessionsbindingen i konstruktion med ekstern possessor hvor IO er semantisk bundet til del-helhed-relationen. Ved frit IO til 
tilvejebringelsesverber er der ingen af de ovennævnte bindinger inden for sætningen, men der kan som sagt ses tendenser til den senere dominerende pragmatiske binding til regulative kontekster.

I forhold til den diakrone udvikling kan man samlet sige at den frihed til at tilføje ikke-valensbundne IO'er med Interessentbetydning som ifølge Høysgaard stadig skulle herske i hans samtidige 1700-talssprog, kun træder frem hos Leonora Christina i stærkt begrænset omfang. De få forekomster i Jammers Minde er naturligvis i første omgang en indikation af lav frekvens i sprogbrugen som ikke i sig selv beviser at Høysgaards beskrivelse af systemiske muligheder er ukorrekt, men hvis Leonora Christina i sit sprogsystem har haft konstruktion med frit IO som en relativt uindskrænket mulighed, udnytter hun den hvert fald kun uhyre sparsomt i sin sprogbrug. Ligeledes viser de forskellige IO-bindinger opsummeret ovenfor at det indirekte objekt, som det fremstår i fammers Minde, stort set altid er bundet til sin kontekst, også når det i øvrigt er frit.

\section{Om forfatteren}

Peter Juul Nielsen, ph.d., Institut for Sprog og Kommunikation ved Syddansk Universitet.

\section{Litteratur}

Barðdal, J. (2007): The semantic and lexical range of the ditransitive construction in the history of (North) Germanic. Functions of Language 14.1, 9-30.

Barðdal, J., K.E. Kristoffersen \& A. Sveen (2011): West Scandinavian ditransitives as a family of constructions: With a special attention to the Norwegian 'V-REFL-NP' construction. Linguistics 49.1, 53-104.

Brunsmand, J. (1674): Koge Huskors. Udgave ved. A. Bæksted (1953). København: Munksgaard.

Butt, M. (2010): The light verb jungle: still hacking away. I: Complex predicates: Cross-linguistic perspectives on event structure. M. Amberber, B. Baker \& M. Harvey (red.). Cambridge: Cambridge University Press, 48-78.

Colleman, T. (2011): Ditransitive Verbs and the Ditransitive Construction: A diachronic perspective. Zeitschrift fir Anglistik und Amerikanistik 59, 387-410.

Colleman, T. \& B. De Clerck (201 1): Constructional semantics on the move. On semantic specialization in the English double object construction. Cognitive Linguistics 22.1, 183-209. 
GDS: se Hansen \& Heltoft (2011).

Haspelmath, M. (1999): External Possession in a European Areal Perspective. I: External possession. D.L. Payne \& I. Barshi (red.). Ansterdam:John Benjamins, 109-135.

Hansen, E. \& L. Heltoft (2011): Grammatik over det Danske Sprog (GDS). København: Det Danske Sprog- og Litteraturselskab, Syddansk Universitetsforlag.

Heltoft, L. (2014): Constructional change, paradigmatic structure and the orientation of usage processes. I Usage-Based Approaches to Language Change. E. Coussé \& F. von Mengden (red.). Amsterdam: John Benjamins, 203-241.

Heltoft, L. (2019): Fra gammeldansk til nutidsdansk. I Dansk Sproghistorie bd. III. Ebba Hjorth et al. (red.). København: Det Danske Sprog- og Litteraturselskab, 129-225.

Høysgaard, J.P. (1752): Methodisk Forsøg til en fuldstendig dansk Syntax. København. (= Bertelsen, Henrik (red.), Danske Grammatikere V. Det danske Sprog- og Litteraturselskab [1919-1920]).

Ibsen, U. \& P. Refstrup (2002): Det Indirekte Objekt: Om forholdet mellem det indirekte objekt og det middelbare indirekte objekt $i$ dansk. Speciale, Roskilde Universitetscenter.

Kalkar, Otto (1976). Ordbog til det aldre danske sprog (1300-1700), 2. udgave. København: Akademisk Forlag.

Leonora Christinas Fammers Minde (1998): Diplomatarisk udgave ved P. L. Hjorth og M.A. Nielsen. København: Det danske Sprog- og Litteraturselskab

Nielsen, P.J. \& L. Heltoft (under udgivelse): Indexicality across the boundaries of syntax, semantics and pragmatics: The constructional content of the Danish free indirect object. I Ditransitive Constructions in Germanic Languages: Diachronic and Synchronic Aspects. T. Colleman, M. Rothlisberger \& E. Zehentner (red.). Amsterdam: John Benjamins.

ODS: Ordbog over det Danske Sprog, online-udgave, ordnet.dk/ods /

Palladius, P. (c. 1543). Visitatsbogen. Udgave ved L. Jacobsen, Peder Palladius' Danske Skrifter, bd. 5, 1926. København: S.S. Thiele.

Zehentner, E. (2017): Ditransitives in Middle English: on semantic specialisation and the rise of the dative alternation. English Language and Linguistics 22.1, 149-175.

Zúñiga, F. \& S. Kittilä (2019): Grammatical Voice. Cambridge: Cambridge University Press. 